\title{
Tiny homes as logistical challenges in a space colony
}

\begin{abstract}
The question is not if we will colonize space, but when we will colonize space. The basic questions left for us to ponder are: Who? What? Where? How? Why? And When? Mankind's nature is to explore, it is what we do. As a result, the cost of space settlements needs to be inexpensive to become a true reality for ordinary people. New uses will grow as the cost is reduced. Our commentary of research interest suggests that the most sustainable space colonization will emerge from individual travellers who care enough about their tiny habitats, or Tiny Homes, to make them liveable and individual homes on other worlds.
\end{abstract}

Keywords: tiny homes, space colony, space architecture, space colonization

\author{
Volume I Issue I - 2017
}

\author{
Cokley J, ' Mc Auliffe M, ${ }^{2}$ Heinrich $\mathrm{P}^{2}$ Rankin \\ W, ${ }^{3}$ Hanrick $P^{4}$ \\ 'School of Humanities, Griffith University, Australia \\ ${ }^{2}$ Queensland University of Technology, Australia \\ ${ }^{3}$ College of Aeronautics, Florida Institute of Technology, USA \\ ${ }^{4}$ Centre of Gender, Leadership and Social Sustainability, Monash \\ University, Australia
}

Correspondence: William Rankin, Associate Professor, College of Aeronautics, Florida Institute of Technology, USA, Tel 954-8069840, Fax 954-674-8059, Email Wrankin@fit.edu

Received: May 10, 2017 | Published: May 31, 2017

\section{Introduction}

When American singer-songwriter Malvina Reynolds composed, the folk hit Little Boxes in 1963 it was held up as a protest song about the sameness and predictability contemporary American architecture and 20th century society. More than half a century later, however, the habitat pendulum has swung and the Tiny House/Home movement is gaining momentum among sustainability activists, environmentalists, and a new breed of architects, who must rethink and incorporate inexpensive and realistic, as well as adaptable designs, into these tiny habitats them to become a reality for ordinary people in space colonization efforts.

Since the question is not whether we will colonize the Moon or Mars, but who, what, where, how, why, and when we will colonize these new habitats, therefore, these habitats must also reflect a sense of connectivity and situational awareness to avoid social isolation. This is important not for reasons of survivability in space, but also for marketability of the space living experience and for desirability for communities to move to space. Space architecture $(\mathrm{SA})^{1-6}$ is a relatively new phenomenon which connects architecture either with scientific disciplines or with space technologies. It involves physiology, psychology, and sociology, and is primarily founded in engineering (especially aerospace engineering). Focusing on the totality of the built environment, it aims to consider issues beyond engineering components and systems to gain a broader understanding of the issues that affect design outcomes and ultimately, success in human environments.

\section{Methodology}

Our research interest methodology is based on an extensive review of the literature and data from readily available industry and peer reviewed sources. Our review has revealed that there is little doubt that the first space colony will be composed primarily of highly trained and well-educated astronauts. The population most likely will be international, mostly male, and contain both military and civilians alike. Materials, energy, transportation, communication, life support, and radiation are but a few of the key issues that will have to be addressed. But for space settlement to be feasible, our review suggests that they must being expensive. In addition to cost, the design and aesthetics of small-space habitats, or Tiny Homes, should more strongly reflect design considerations of the individual settlers. Finally, we have been unable to find any prior research that has been conducted on the comparison of Tiny Homes, the Makers Movement, and space colonization.

\section{Discussion}

\section{Tiny homes}

Tiny Houses (also Tiny Homes, Tiny Abodes, and Tiny Habitats) are more than just an architectural fad: they fit on the historic spectrum of economical, transportable housing which in the 21 st century has become the phenomenon of "People Who Move".?
i. Sustainable footprint ${ }^{8}$
ii. Itinerant traders ${ }^{9}$
iii. Baby Boomers ${ }^{10}$
iv. Survivalists
v. Refugees
vi. Mining camps

\section{Tiny homes and space architecture}

Space architecture considers habitat as well as research facilities including labs, stowage areas, and energy generation systems. Tiny Homes can be considered as having a close connection with space architecture but provide more specific consideration of the interior architecture and design of living habitats, rather than bearing in mind the entire system. This focus on interior configuration is of critical importance. Fluid and transformative interiors are core concepts to Tiny Homes, requiring responsiveness to the multiple daily needs of inhabitants, especially those who require the optimization of every cubic inch.

Tiny Homes also consider space as cubic feet (space in threedimensions), a critical feature of aerospace design, rather than traditional square feet (space in two-dimensions), and a typical feature of earthly design. 


\section{The makers movement}

Tiny Homes also fit contemporary manufacturing processes. The Makers' Movement ${ }^{11,12}$ is a broad description of what has recently been described as open-architecture products (OAP): ${ }^{13}$ "a new class of products comprising a fixed platform and modules that can be added and swapped. Customers can adapt OAP to their needs by integrating modules into the platform. ${ }^{14}$ Anderson, ${ }^{11}$ noted that this movement has caught the attention of many major and emerging players in the tech and corporate worlds, including companies like General Electric (p.31) Intel, Nvidia, AMD, AutoDesk (p.98), Oracle/Java, Ford (p.134), NASA, Atmel, Qualcomm, TI, and 3D Robotics (p.19)

Our research investigates the development of the Makers/ OAP movement and its relationship with key elements of space colonisation and suggests that, despite historical evidence that the military-industrial complex owns space, the most sustainable space colonisation will emerge from individual travellers who care enough about their tiny habitats to make them liveable and individual homes on other worlds. This will also be the most commercially viable and marketable, a suggestion supported by products emerging from Bigelow Aerospace.

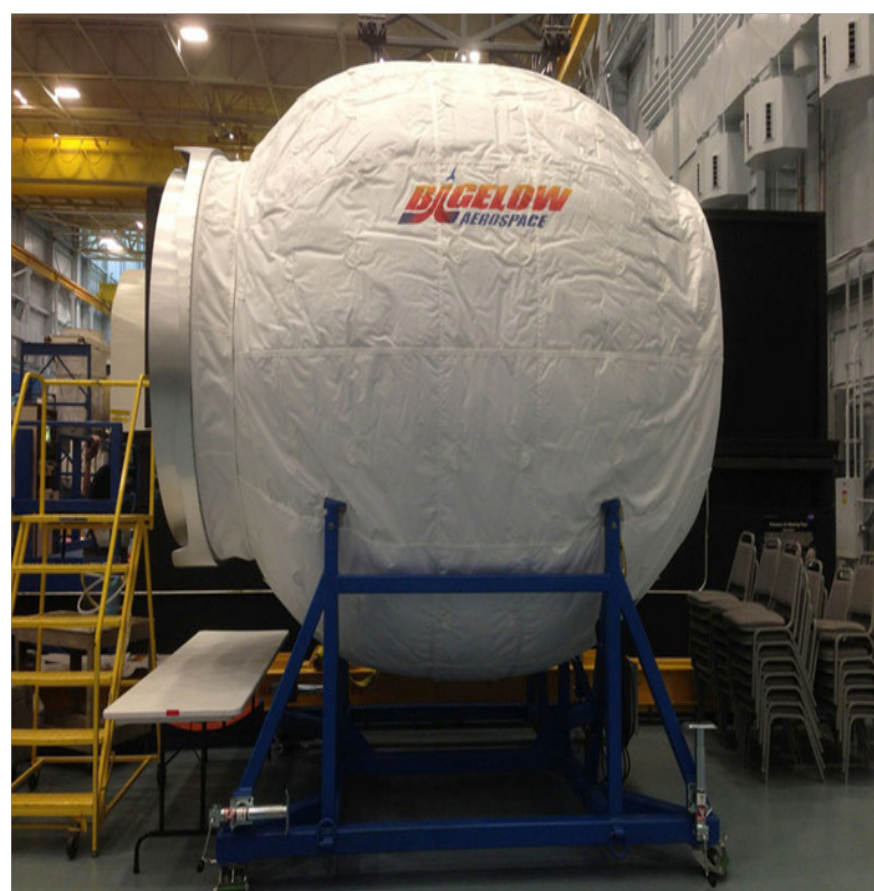

Figure I The OAP idea has progressed to space (Bigelow Aerospace, 2017).

\section{Initial goals of tiny homes}

The initial goals of Tiny Homes in space colonization are to:

i. Support human living and working tasks in a confined space without adversely affecting users' physiological, psychological, and sociological health,

ii. Provide communications and appropriate media to the outside world to avoid isolation, and create a favorable situational awareness one one's place in space,

iii. Integrate multiple tasks and accommodations into small, compact layouts where all tasks cannot have dedicated volume and privacy may be limited, iv. Minimize the amount of materials, mass, and cost,

v. Enable inhabitant self-sufficiency and reuse materials for multiple purposes,

vi. Enable humans to survive in remote locations, and

vii. Enable mobility (when desired).

However, our research suggests that the social make-up of space communities will be more diverse than expected by current space planners ${ }^{15,16}$ and more dependent on design and human factors than is currently evidenced in planning and production. ${ }^{17-19}$

Our work further suggests that the evident humanity of the crew, how they live and their living environments, will be important contributing factors not only to the success of each mission but to the public support and funding for, and subsequently the viability and sustainability of subsequent missions. ${ }^{20-22}$

\section{Our research}

Our research investigates how tiny houses have already developed on Earth, especially regarding:

i. Design,

ii. Liveability

iii. Emotional outcomes relative to functional outcomes, and

iv. The relationship between engineering requirements and liveability requirements, including the obvious, such as exposure to radiation, long-term effects of living in space, and space sickness.

A useful way to discover how people will live and prosper in space is to look at how people like us already live in space.

\section{Design considerations}

The design aesthetics of small-space design should be more strongly reflected in space habitat design. These represent proven strategies based upon current terrestrial Tiny Home designs to improve contentment and comfort within confined environments. This requires early design consideration of spacecraft interiors to prevent a repetition of the ISS designs.

Our team's hypotheses draw on ethno methodological data about how humans make living spaces. ${ }^{23}$

Homemakers look for:

i. Size. Will the space be big enough for purpose but not too big for cost (e.g. cleaning and furnishing)?

ii. Location. What are the prevailing influences for noise, traffic, views?

iii. Price. Is the property affordable?

iv. Kitchen. Oven size is important.

v. Bathrooms. Most Western families need two bathrooms/toilets.

vi. Aesthetics. How clean is the environment, charm (design), which direction is the house facing? Where does the light come from?

vii. Temperature. How is the house cooled or warmed? 


\section{Conclusion}

What will it be like to live in a space community and how can that experience be improved? In the long term, the cost of space settlements needs to be inexpensive to become a true reality for ordinary people. Launch systems will need to be safe, reliable, and capable of carrying thousands, if not millions into space. New uses will grow as the cost is reduced. Globus's ${ }^{24}$ suggestion that uses will include:

i. Settlements for religious groups who want to practice their faith.

ii. Penal colonies

iii. Handicapped that would benefit from the zero-g environment.

iv. Settlements for people with different political or social norms.

v. Finally, those who see the need of building new land rather than taking from another.

At a minimum, space habitat designs should implement solutions such as light colors, natural light sources, and natural materials to improve perception of the space and implement virtual windows to replace the perception of outside space which has been so critical to small space designs. Of critical importance is communications and appropriate media to the outside world to avoid isolation, and create a favorable situational awareness one one's place in space communities of the future.

\section{Acknowledgements}

None.

\section{Conflict of interest}

Author declares that there is no conflict of interest.

\section{References}

1. Broughton HG. Antarctic Research Stations: Parallels for Interplanetary Design. 40th International Conference on Environmental Systems. American Institute of Aeronautics and Astronautics, Barcelona, Spain; 2010. p. 1-12.

2. Harris TS, Weeks EE. Viewing Architectural Design as an Impetus to Spur Outer Space Development. Design Principles and Practices: An International Journal. 2011;5(4):127-148.

3. Häuplik-Meusburger S. Architecture for Astronauts: An Activity-based Approach. Springer Science \& Business Media. 2011.

4. Howe AS, Sherwood B. Out of this world: The new field of space architecture. American Institute of Aeronautics and Astronautics, USA; 2009. p. 421.

5. Rousek T, Eriksson K, Doule O. SinterHab. Acta Astronautica. 2012;74:98-111.

6. Sherwood B. Inhabiting the solar system. Central European Journal of Engineering. 2011;1(1):38-58.

7. Cokley J, Comrie M. People who move and need news: The economic and social value of providing digital journalism services for mobile and remote audiences. Australian Journal of Telecommunications and the Digital Economy. 2013;1(1):1-22.

8. Gabriella. Tiny House Build-Off Grid Ideas and Tips. 2014.
9. Lally S. Gypsies and Travellers: their history, culture and traditions. Community Pract. 2015;88(1):30-33.

10. Patterson I, Pegg, S, Mahadevan R. The Benefits of Short Stay Caravan Travel Based on the Lived Experiences of Grey Caravanners in Australia.Tourism Analysis. 2015;20(5):539-549.

11. Anderson C. Makers: The New Industrial Revolution. Crown Publishing Group, New York; 2012. p. 272.

12. Kennedy EJ, Giampetro Meyer A. Gearing Up for the Next Industrial Revolution: 3D Printing, Home-Based Factories, and Modes of Social Control. Loyola University. Chicago Law Journal. 2015;46(4):955-1077.

13. Koren Y, Hu S, Gu P, et al. Open-architecture products. CIRP Annals-Manufacturing Technology. 2013;62(2):719-729.

14. Tanenbaum JG, Tanenbaum K. Fabricating Futures: Envisioning Scenarios for Home Fabrication Technology Creativity in the Digital Age. Springer, London, UK; 2015. p. 193-221.

15. Babidge S, Cokley J, Gordon F, et al. Making media work in space: an interdisciplinary perspective on media and communication requirements for current and future space communities. International Journal of Astrobiology. 2005;4(3-4):259-268.

16. Cokley J, Rankin WB, Söhnlein G. Astronauts as Audiences: Characteristics of the First Space Communities. International Journal of Applied Aviation Studies. 2005;5(1):167-181.

17. Cokley J, Kavanagh L, Johnson Woods T, et al. We're in Their Hands: Teen Space Settlement Designs Display Engineering and Active-Learning Skills but Their Plans Fall Short on" Liveability". 7th Australian Space Science Conference. Sydney, Australia; 2007. p. 9-20.

18. Cokley J, Mc Auliffe M. Unexpected Issues and Solutions: Emerge from Environmental Manipulation Strategy. Journal of Futures Studies. 2011;15(4):159-180.

19. Rankin W, Cokley J. Enhancing Life in the Hyper-Surveillance MiniWorld of a Space Station: The Role of Situation Awareness, Communication, and Reality TV in the Life of Astronauts. International Journal of Applied Aviation Studies. 2006;6(2):283-298.

20. Cokley J, Angus D. The effect that robots instead of spacemen landing on Mars can have on spacecraft development. First Monday. 2014;19(1).

21. Cokley J, Rankin W, Heinrich P, et al. Comparison of historic exploration with contemporary space policy suggests a retheorisation of settings. JBIS-Journal of the British Interplanetary Society. 2013;66(7-8):233-241.

22. Cokley J, Rankin W, McAuliffe MB, et al. The ultimate edge: The case for planning media for sustaining space communities. In A. Taylor, Andrew et al. editors. Settlements at the Edge: Remote Human Settlements in Developed Nations. Edward Elgar Publishing Ltd, Cheltenham, England; 2016. p. 405-426.

23. Garfinkel H. Ethnomethodology's program: Working out Durkheim's aphorism. In: Anne Warfield Rawls, editor. Rowman, Littlefield Publishers, USA; 2002. 320 p.

24. Globus A. Space settlement basics. 2004.

25. Bigelow Aerospace. Beam mock-up. 2017.

26. Simon M, Toups L. Innovation in Deep Space Habitat Interior Design: Lessons Learned from Small Space Design in Terrestrial Architecture. AIAA Space 2014 Conference and Exposition. NASA Langley Research Center, Hampton, USA and NASA Johnson Space Center, Houston, USA; 2014. 